\title{
EFEKTIVITAS PEMODELAN DAN PEMBELAJARAN BERBASIS PROJEK UNTUK MENINGKATKAN KEMAMPUAN MENYUSUN RENCANA PELAKSANAAN PEMBELAJARAN
}

\author{
Rahayu Pujiastuti, Luluk Isani Kulup \\ Universitas PGRI Adi Buana Surabaya \\ rahayu_pujiastuti@unipasby.ac.id \\ luluk@unipasby.ac.id \\ Diterima: 27 November 2018 \\ Publikasi: 27 Februari 2019 \\ DOI: http://dx.doi.org/10.32528/bb.v4i1.1871
}

\begin{abstract}
ABSTRAKS
Tujuan penelitian ini mendeskripsikan (1) penerapan pemodelan dan pembelajaran berbasis projek pada mata kuliah Perencanaan PBSI untuk meningkatkan kemampuan mahasiswa menyusun RPP, (2) peningkatan hasil belajar mahasiswa untuk menyusun RPP setelah menggunakan pemodelan dan pembelajaran berbasis projek, dan (3) respon mahasiswa setelah menggunakan pemodelan dan pembelajaran berbasis projek untuk meningkatkan kemampuan mahasiswa menyusun RPP. Subjek penelitian ini adalah dosen pada mata kuliah pada mata kuliah Perencanaan PBSI dan mahasiswa program studi pendidikan bahasa dan sastra Indonesia. Data dikumpulkan dengan teknik observasi, tes, dan angket. Untuk analisis data digunakan persentase dan deskripsi. Hasil penelitian memberi informasi tiga hal, yaitu (1) terjadi peningkatan penerapan pemodelan dan pembelajaran berbasis projek pada mata kuliah Perencanaan PBSI untuk meningkatkan kemampuan mahasiswa menyusun RPP; tampak pada aktivitas dosen dan aktitas mahasiswa dari kriteria 'baik' pada menjadi 'sangat baik'; (2) terjadi peningkatan hasil belajar mahasiswa untuk menyusun RPP setelah menggunakan pemodelan dan pembelajaran berbasis projek dari kriteria 'cukup' menjadi 'baik'; (3) terjadi peningkatan respon mahasiswa setelah menggunakan pemodelan dan pembelajaran berbasis projek untuk meningkatkan kemampuan mahasiswa menyusun RPP dari kriteria 'cukup' menjadi 'baik'.
\end{abstract}

Kata Kunci: RPP, pemodelan, pembelajaran berbasis projek.

\begin{abstract}
This study aims to describe (1) the application of project-based modeling and learning in Indonesian Language and Literature Learning Planning courses to improve students ability to develop learning implementation plans, (2) increase student learning outcomes to develop learning implementation plans after using project-based learning and modeling, and (3) student responses after using project-based modeling and learning to improve the ability of students to develop plans for implementing learning. The subjects of this study were lecturers in courses in Indonesian Language and Literature Learning Planning courses and students of Indonesian language and literary education study programs. Data is collected by observation, tests, and questionnaires. For data analysis used percentages and descriptions. The results of the study provide information on three things, namely (1) an increase in the application of project-based modeling and learning in the Indonesian Language and Literature Learning Planning course to improve the ability of students to develop plans for implementing learning; seen in the lecturer activities and student activities from the criteria 'good' to being 'very good'; (2) there is an increase in student learning outcomes to develop a learning implementation plan after using project-based modeling and learning from the criteria 'enough' to be 'good'; (3) there is an increase in student responses after using project-based modeling and learning to improve the ability of students to develop learning implementation plans from the criteria 'enough' to be 'good'.
\end{abstract}

Keywords: plan for implementing project-based learning, modeling, learning 


\section{PENDAHULUAN}

Bagi para mahasiswa Fakultas Keguruan Dan Ilmu Pendidikan, termasuk mahasiswa Program Studi Pendidikan Bahasa Dan Sastra Indonesia (Prodi PBSI), memunyai kemampuan menyusun rencana pelaksanaan pembelajaran (RPP) bersifat mutlak. Dengan memunyai kemampuan tersebut berarti para mahasiswa memunyai kompetensi pedagogis. Dalam Undang-undang Nomor 14 Tahun 2005 Pasal 10 (Ayat 1) dinyatakan bahwa pendidik wajib memiliki kompetensi profesional, kepribagian, sosial, juga kompetensi pedagogik.

Menurut Mulyasa, (2008), dalam Standar Nasional Pendidikan tentang kompetensi pendidik dinyatakan bahwa kompetensi pedagogis adalah kemampuan mengelola pembelajaran. Kompetensi tersebut, meliputi kemampuan (1) memahami karakteristik para peserta didik; (2) merancang, melaksanakan, dan menilai pembelajaran; (3) menerapkan teori pembelajaran yang relevan dengan peserta didik dan karakteristik mata pelajaran, misalnya melaksanakan pembelajaran yang inovatif.

Kemampuan menyusun RPP adalah salah satu kemampuan pedagogis. Dalam Permendikbud Nomor 22 Tahun 2016 tentang Standar Proses Pendidikan Dasar dan Menengah dijelaskan bahwa RPP adalah rencana kegiatan pembelajaran tatap muka untuk satu pertemuan atau lebih. RPP dikembangkan dari silabus untuk mengarahkan kegiatan pembelajaran peserta didik dalam upaya mencapai kompetensi dasar (Kemdikbud, 2016).
Kemampuan menyusun RPP penting untuk dimiliki. Dengan memiliki kemampuan tersebut, para mahasiswa tidak hanya memeroleh bekal ketika menempuh mata kuliah Magang II (microteaching) maupun Magang III (real teaching), tetapi juga memiliki bekal untuk menjadi pendidik yang dapat melaksanakan pembelajaran secara terarah. Hal tersebut disebabkan dalam RPP terdapat empat standar kompetensi penting dalam pembelajaran, yaitu (1) standar kompetensi lulusan yang tampak pada kompetensi inti, kompetensi dasar, dan tujuan pembelajaran, (2) standar isi yang tampak pada indikator dan materi, (3) standar proses yang tampak pada pendekatan, model, metode, skenario, dan media pembelajaran, (4) standar penilaian yang tampak pada teknik penilaian dan bentuk instrumen penilaiannya.

Pentingnya RPP ternyata tidak identik dengan kepedulian pihak terkait. Hal tersebut dapat dibuktikan melalui hasil penelitian yang ada selama ini. Tidak banyak penelitian tentang kemampuan menyusun RPP pada para mahasiswa, termasuk mahasiswa Prodi PBSI. Penelitian yang ada, pada umumnya berkaitan dengan bidang ilmu yang ditekuni. Contohnya, penelitian semantis, psikolinguistis, pragmatis, feminis, nilai sosial, dan masih banyak lagi. Apabila dijumpai penelitian yang berhubungan dengan kemampuan menyusun RPP, yang menjadi subjek penelitian adalah para guru, bukan para mahasiswa.

Pada penelitian terdahulu diperoleh informasi bahwa kemampuan menyusun 
RPP para pendidik masih rendah (Safardi, 2009; Wijaya, 2011). Kemampuan yang masih rendah tersebut bisa terjadi karena pada saat menjadi mahasiswa bekal yang dimiliki masih kurang. Oleh karena itu, sangat penting mengetahui kemampuan para peserta didik untuk menyusun RPP.

Pada pengamatan awal yang dilakukan ternyata kemampuan menyusun RPP mahasiswa Prodi PBSI Universitas Adi Buana Surabaya masih kurang. Dari 35 mahasiswa yang mencapai kriteria ketuntasan minimal (KKM) 70 hanya 15 mahasiswa atau $43 \%$. Penyebabnya, yaitu para mahasiswa (1) kurang memiliki pengetahuan teoretis tentang penyusunan RPP; (2) kurang memiliki pengetahuan tentang contoh RPP; (3) kurang memeroleh kesempatan untuk mengalami pembelajaran yang dapat atau mampu memberdayakan kemampuan berpikir analitis kritis.

Berdasarkan masalah tersebut ditetapkan solusi berupa pembelajaran dengan pemodelan yang dikombinasi dengan pembelajaran berbasis projek. Menurut Priyatni (2002) dan Nurhadi (2005), pemodelan merupakan bagian dari pembelajaran kontekstual yang dilakukan dengan cara menyajikan contoh atau mendemonstrasikan materi pelajaran. Melalui model yang digunakan dalam pembelajaran, para peserta didik dapat mencontoh, meniru, serta belajar untuk melakukan sesuai dengan model yang diberikan. Melalui pemodelan, pembelajaran tidak hanya bersifat teoretis, tetapi juga praktis. Pengetahuan yang diperoleh dari model atau contoh berbagai sumber belajar dapat digunakan untuk aplikasi.

Untuk lebih dapat mencapai tujuan pembelajaran, pemodelan dapat dikombinasi dengan pembelajaran yang juga berorientasi untuk menghasilkan produk. Dalam penelitian ini, model yang dimaksud, yaitu pembelajaran berbasis projek. Menurut Klein et al. (2009), pembelajaran berbasis projek adalah pembelajaran yang menggunakan projek atau suatu kegiatan sebagai media. Pada pembelajaran tersebut, secara aktif, para peserta didik melakukan eksplorasi, penilaian, interpretasi, sintesis, dan pengolahan informasi untuk menghasilkan berbagai bentuk hasil belajar.

Menurut Grant (2002), dalam pembelajaran berbasis projek tersebut, para peserta didik melakukan pembelajaran secara induktif sehingga terlibat secara aktif, baik fisik dan mental. Peserta didik dapat bernalar atau berpikir analitis kritis terhadap permasalahan yang dinyatakan melalui pertanyaan yang berbobot, nyata, dan relevan.

The George Lucas Educational Foundation (2005) menyatakan ada enam langkah pembelajaran berbasis projek. Langkah secara urut, yaitu para peserta didik (1) membuat pertanyaan esensial yang dapat digunakan untuk menentukan fenomena atau topik, (2) membuat desain atau rancangan langkah-langkah penyelesaian projek, (3) menyusun jadwal pelaksanaan projek, (4) menyelesaikan projek dengan monitoring pendidik, (5) menyusun laporan dan presentasi/ publikasi hasil projek, serta (6) mengevaluasi proses dan hasil projek. 
Baker et al. (2011) menambahkan bahwa pembelajaran berbasis projek berfokus pada konsep dan prinsip sehingga memfasilitasi peserta didik untuk memecahkan masalah serta melakukan tugas bermakna sehingga menghasilkan produk nyata.

Dalam penelitian ini, pembelajaran dengan pemodelan yang berkombinasi pembelajaran berbasis projek berarti pembelajaran yang dilakukan secara induktif dibantu dengan penyajian model atau contoh yang berupa RPP dari beberapa sekolah. Melalui contoh-contoh tersebut, para mahasiswa berperan aktif dalam kegiatan bernalar atau berpikir analitis kritis sehingga mampu memilih dan menyepakati RPP yang tepat untuk dikembangkan. Hasil berpikir kritis tersebut pada akhirnya dapat digunakan sebagai model untuk menghasilkan produk RPP yang baik dan benar.

Berdasarkan hal tersebut, tujuan penelitian ini, yaitu mendeskripsikan (1) penerapan pemodelan dan pembelajaran berbasis projek pada mata kuliah Perencanaan PBSI untuk meningkatkan kemampuan mahasiswa menyusun RPP, (2) peningkatan hasil belajar mahasiswa untuk menyusun RPP setelah menggunakan pemodelan dan pembelajaran berbasis projek, dan (3) respon mahasiswa setelah menggunakan pemodelan dan pembelajaran berbasis projek untuk meningkatkan kemampuan mahasiswa menyusun RPP.

Melalui penelitian ini, mahasiswa dan dosen dapat memeroleh manfaat. Bagi mahasiswa, hasil penelitian ini bermanfaat untuk memberi bekal untuk menempuh mata kuliah lain, yaitu Magang II dan Magang III. Selain itu, para mahasiswa memeroleh pemodelan dan pengalaman untuk melakukan pembelajaran inovatif.

Bagi dosen, hasil penelitian ini dapat memberi masukan tentang cara kreatif mengembangkan pembelajaran secara inovatif. Selain itu, dosen memeroleh informasi untuk melakukan pembelajaran yang dapat mengeksplor kemampuan berpikir analitis kritis dari mahasiswa sehingga berguna untuk meningkatkan kualitas proses dan hasil belajar para mahasiswa.

\section{METODE PENELITIAN}

Penelitian ini termasuk penelitian tindakan kelas. Oleh karena itu, tahapan yang digunakan, meliputi perencanaan, pelaksanaan, observasi dan evaluasi, serta refleksi. Keempat tahap tersebut dilakukan dalam satu siklus. Informasi pada setiap siklus berguna untuk melakukan siklus selanjutnya. Maksudnya, ketika pada suatu siklus belum diperoleh hasil yang ditetapkan akan dilakukan siklus berikutnya. Kekuatan pada pelaksanaan suatu siklus dipertahankan, sedangkan kelemahan atau kekurangannya diperbaiki pada siklus berikutnya.

Subjek penelitian ini adalah dosen mata kuliah Perencanaan PBSI dan 35 mahasiswa Prodi PBSI. Para mahasiswa tersebut pada saat penelitian sedang menempuh mata kuliah Perencanaan PBSI.

Untuk mengumpulkan data digunakan teknik observasi, tes, dan angket. Instrumen berupa lembar observasi, soal tes uraian, dan daftar cek list. Analisis data 
Jurnal Belajar Bahasa, ISSN 2502-5864, E-ISSN 2503-0329

Volume 4, No. 1, Februari 2019

dilakukan dengan cara persentase dan deskripsi.

\section{PEMBAHASAN}

\section{a. Penerapan Pemodelan}

dan

\section{Pembelajaran Berbasis projek}

Ada dua hal yang diteliti pada penerapan pembelajaran, yaitu aktivitas dosen dan mahasiswa. Pada kedua aktivitas tersebut digunakan instrumen yang sama sehingga dapat digunakan untuk observasi awal, siklus 1 , dan siklus 2 , meskipun berbeda model dan metode pembelajaran.

Pada observasi awal, dosen menggunakan metode ceramah, sedikit bertanya-jawab, kemudian memberi tugas untuk dikumpulkan. Pada siklus 1 dan 2, digunakan pembelajaran yang memang diterapkan sebagai solusi dari kesulitan belajar mahasiswa. Pembelajaran yang dimaksud adalah penerapan pemodelan dan pembelajaran berbasis projek.

Butir-butir instrumen terdiri atas tiga kegiatan, yaitu pendahuluan, inti, dan penutup. Skor yang digunakan 1 s.d. 4 yang berarti kriteria 'kurang', 'cukup', 'baik', dan 'sangat baik'. Keempat butir skor tersebut diterapkan pada aktivitas dosen dan aktivitas mahasiswa.

\section{1) Aktivitas Dosen}

Hasil aktivitas dosen pada observasi awal, siklus 1, dan siklus 2 dirinci pada tabel berikut.

Tabel 1 Hasil Observasi Aktivitas Dosen

\begin{tabular}{llll}
\hline \multirow{2}{*}{ No Aktivitas } & \multicolumn{3}{c}{ Hasil Observasi } \\
\cline { 2 - 3 } & Ob & Sk 1 & Sk 2 \\
\hline Kegiatan Pendahuluan & &
\end{tabular}

\begin{tabular}{|c|c|c|c|c|}
\hline 1. & $\begin{array}{l}\text { Membuka pembel- } \\
\text { ajaran secara efek- } \\
\text { tif }\end{array}$ & 3 & 3 & 4 \\
\hline 2. & $\begin{array}{l}\text { Mengaitkan pem- } \\
\text { belajaran dengan } \\
\text { kehidupan nyata } \\
\text { (kontekstual) }\end{array}$ & 2 & 3 & 3 \\
\hline \multicolumn{5}{|c|}{ Kegiatan Inti } \\
\hline 3. & $\begin{array}{l}\text { Mengembangkan } \\
\text { materi sesuai de- } \\
\text { ngan kompetensi } \\
\text { yang dicapai serta } \\
\text { sistematis }\end{array}$ & 3 & 4 & 4 \\
\hline 4. & $\begin{array}{l}\text { Menguasai materi } \\
\text { (kelengkapan, } \\
\text { kebenaran konsep, } \\
\text { keluasan, dan } \\
\text { kedalaman) }\end{array}$ & 3 & 4 & 4 \\
\hline 5. & $\begin{array}{l}\text { Menerapkan pen- } \\
\text { dekatan, model, } \\
\text { dan metode yang } \\
\text { tepat }\end{array}$ & 2 & 3 & 4 \\
\hline 6. & $\begin{array}{l}\text { Menggunakan vari- } \\
\text { asi interaksi yang } \\
\text { membudayakan } \\
\text { pemikiran positif }\end{array}$ & 2 & 3 & 3 \\
\hline 7. & $\begin{array}{l}\text { Mengorganisasi } \\
\text { sumber belajar } \\
\text { dengan baik }\end{array}$ & 3 & 3 & 4 \\
\hline 8. & $\begin{array}{l}\text { Menggunakan me- } \\
\text { dia secara efektif } \\
\text { agar mahasiswa } \\
\text { aktif untuk berpikir } \\
\text { analitis kritis }\end{array}$ & 2 & 4 & 4 \\
\hline \multicolumn{5}{|c|}{ Kegiatan Penutup } \\
\hline 9. & $\begin{array}{l}\text { Melakukan refleksi } \\
\text { dan penguatan }\end{array}$ & 3 & 3 & 4 \\
\hline 10. & $\begin{array}{l}\text { Melakukan penilai- } \\
\text { an baik proses } \\
\text { maupun produk }\end{array}$ & 3 & 3 & 4 \\
\hline \multicolumn{2}{|c|}{ Jumlah } & 26 & 33 & 38 \\
\hline \multicolumn{2}{|c|}{ Persentase (\%) } & 65 & 83 & 95 \\
\hline
\end{tabular}

Berdasarkan data pada Tabel 1, aktivitas dosen pada observasi awal memunyai skor 26 atau 65\%. Ada empat aktivitas dosen, yaitu aktivitas 2, 5, 6, dan 8 yang mendapat skor 2 (cukup). Hal itu menjadi catatan ketika penerapan pemodelan dan pembelajaran berbasis projek. Pada aktivitas 2, dosen hanya mengaitkan 
pembelajaran dengan kebutuhan mahasiswa untuk memeroleh bekal ketika menjadi pendidik. Padahal, ada beberapa manfaat lain yang dapat diperoleh. Pada aktivitas 5 dan 6 , dosen hanya menggunakan metode ceramah, sedikit tanya-jawab kemudian penugasan. Oleh karena itu, dalam pembelajaran, variasi interaksi tidak maksimal dan mahasiswa cenderung pasif. Pada aktivitas 8 , setelah menjelaskan dengan ceramah, dosen hanya memberikan satu contoh RPP kemudian mahasiswa diberi tugas.

Pada siklus 1 penerapan pemodelan dan pembelajaran berbasis projek, aktivitas dosen memeroleh skor 33 atau 83\%. Pada tujuh aktivitas telah diperoleh skor 3 (baik), sedangkan pada tiga aktivitas diperoleh skor 4 (sangat baik). Ketiga aktivitas tersebut terkait dengan materi serta keefektifan pemanfaatan media pembelajaran. Pada siklus 1 , dosen telah mengembangkan materi secara sistematis, lengkap, ada kejelasan konsep, serta memunyai tingkat keluasan dan kedalaman yang tepat. Selain itu, dosen telah memanfaatkan media pembelajaran secara efektif sehingga dapat digunakan sebagai sarana untuk berpikir kritis dan menyampaikan pesan pembelajaran.

Hal yang penting dicermati pada siklus 1 ini, yaitu pada saat menerapkan pembelajaran berbasis projek pada aktivitas 5, dosen masih mendapat belum mencapai skor maksimal 4. Dari enam langkah pembelajaran berbasis projek, ada empat langkah yang mendapat skor 3, yaitu (1) menggiring mahasiswa pada pertanyaan esensial, (2) mendampingi mahasiswa untuk membuat desain penyelesaian projek, (3) memonitor penyelesaian projek, dan (4) mendampingi mahasiswa saat presentasi/publikasi hasil projek.

Pada siklus 2, penerapan dilakukan dengan mencermati refleksi pada siklus 1 . Keunggulan pada siklus 1 dipertahankan, sedangkan kelemahannya diperbaiki. Hasil yang diperoleh, yaitu terjadi peningkatan pada aktivitas dosen dengan memeroleh skor 38 atau 95\%. Aktivitas dosen pada siklus 1 yang masih mendapat skor 3 banyak yang meningkat menjadi skor 4 pada siklus 2. Aktivitas-aktivitas utama pada penerapan pemodelan dan pembelajaran berbasis projek, termasuk empat langkah yang masih mendapat skor 3 , pada siklus 2 telah meningkat menjadi skor 4.

\section{2) Aktivitas Mahasiswa}

Untuk aktivitas mahasiswa juga diteliti mulai observasi awal, siklus 1 , dan siklus 2 . Aktivitas mahasiswa ini memiliki poin observasi yang selaras dengan aktivitas dosen.

Hasil observasi aktivitas mahasiswa secara keseluruhan, mulai observasi awal, siklus 1 , dan siklus 2 dapat dilihat pada tabel berikut.

Tabel 2 Hasil Observasi Aktivitas Mahasiswa

\begin{tabular}{|c|c|c|c|c|}
\hline \multirow{2}{*}{ No } & \multirow{2}{*}{ Aktivitas } & \multicolumn{3}{|c|}{ Hasil Observasi } \\
\hline & & Obs & Sk 1 & Sk 2 \\
\hline \multicolumn{5}{|c|}{ Kegiatan Pendahuluan } \\
\hline \multirow[t]{3}{*}{1.} & Bersikap serius & $C: 20$ & $\mathrm{C}: 7$ & B:17 \\
\hline & dan responsif & $B: 15$ & $\mathrm{~B}: 25$ & SB:18 \\
\hline & $\begin{array}{l}\text { ketika dosen } \\
\text { membuka pem- } \\
\text { belajaran }\end{array}$ & & SB:3 & \\
\hline
\end{tabular}


Volume 4, No. 1, Februari 2019

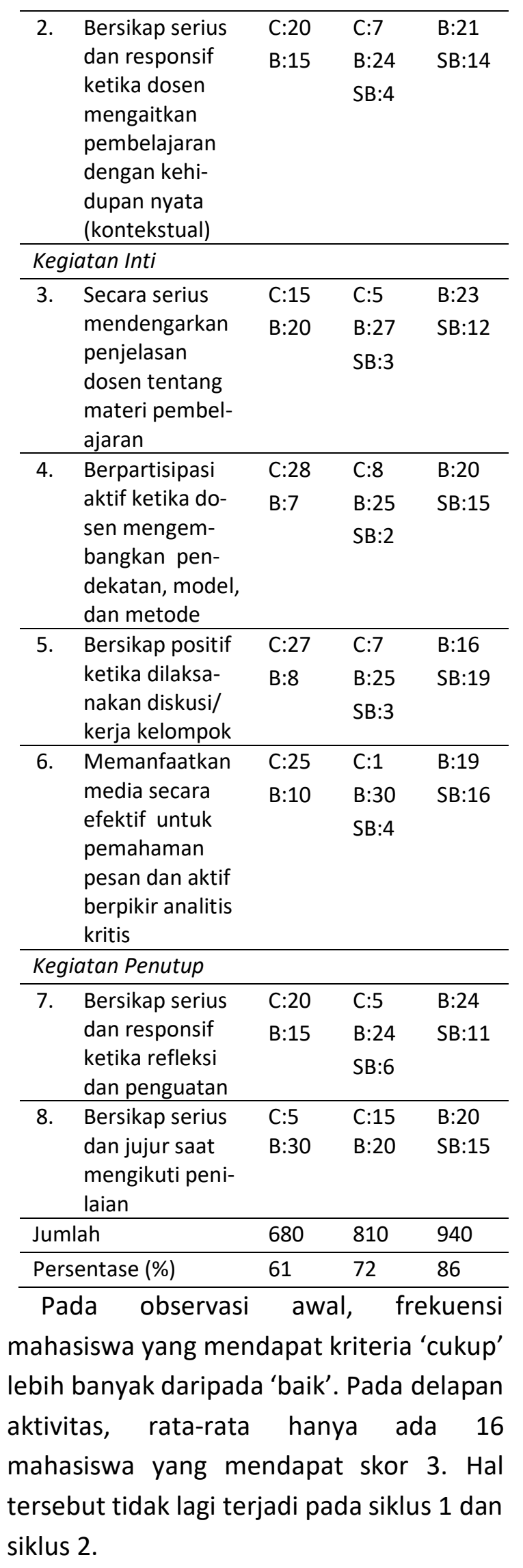

Pada siklus 1 rata-rata ada 25 mahasiswa yang mendapat skor 3 dan ratarata ada 4 mahasiswa yang mendapat skor 4. Pada siklus 2 tidak ada mahasiswa yang mendapat skor 2, tetapi skor 3 dan 4. Pada siklus 2 terjadi peningkatan karena ratarata ada 20 mahasiswa yang mendapat skor 3 dan rata-rata ada 14 mahasiswa yang mendapat skor 4 .

Berikut ini kriteria penerapan berdasarkan hasil aktivitas dosen dan aktivitas mahasiswa secara keseluruhan. Tabel 3 Kriteria Hasil Penerapan

\begin{tabular}{|c|c|c|c|c|c|}
\hline \multirow[b]{2}{*}{$\begin{array}{c}\text { Interval } \\
\%\end{array}$} & \multirow[b]{2}{*}{ Kriteria } & \multirow[b]{2}{*}{$\begin{array}{l}\text { Pene- } \\
\text { rapan }\end{array}$} & \multicolumn{3}{|c|}{ Persentase } \\
\hline & & & Obs & $\begin{array}{c}\text { Sk } \\
1 \\
\end{array}$ & $\begin{array}{c}\text { Sk } \\
2 \\
\end{array}$ \\
\hline \multirow[t]{2}{*}{$86-100$} & \multirow{2}{*}{$\begin{array}{c}\text { Sangat } \\
\text { Baik }\end{array}$} & Akt. Dsn & & & 95 \\
\hline & & Akt. Mhs & & & 86 \\
\hline \multirow[t]{2}{*}{$70-85$} & \multirow[t]{2}{*}{ Baik } & Akt. Dsn & & 83 & \\
\hline & & Akt. Mhs & & 72 & \\
\hline \multirow[t]{2}{*}{$60-69$} & \multirow[t]{2}{*}{ Cukup } & Akt. Dsn & 65 & & \\
\hline & & Akt. Mhs & 61 & & \\
\hline \multirow[t]{2}{*}{$41-59$} & \multirow[t]{2}{*}{ Kurang } & Akt. Dsn & & & \\
\hline & & Akt. Mhs & & & \\
\hline \multirow[t]{2}{*}{$0-40$} & \multirow{2}{*}{$\begin{array}{l}\text { Sangat } \\
\text { Kurang }\end{array}$} & Akt. Dsn & & & \\
\hline & & Akt. Mhs & & & \\
\hline
\end{tabular}

Berdasarkan tabel tersebut, aktivitas dosen mengalami peningkatan dari $65 \%$ dengan kriteria 'cukup' pada observasi awal menjadi $83 \%$ dengan kriteria 'baik' pada siklus 1 dan lebih meningkat menjadi 95\% dengan kriteria 'sangat baik' pada siklus 2. Demikian juga, aktivitas mahasiswa mengalami peningkatan dari $61 \%$ dengan kriteria 'cukup' pada observasi awal menjadi $72 \%$ dengan kriteria 'baik' pada siklus 1 dan lebih meningkat menjadi $86 \%$ dengan kriteria 'sangat baik' pada siklus 2.

Peningkatan penerapan pemodelan dan pembelajaran berbasis projek dilihat secara jelas pada grafik berikut ini. 


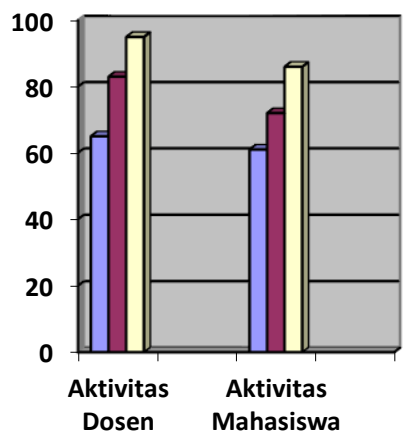

\section{Grafik 1 Peningkatan Penerapan Pembelajaran}

\section{b. Peningkatan Hasil Belajar}

Sebelum dilaksanakan siklus 1 dan 2, terlebih dahulu dilakukan observasi awal untuk mengetahui kemampuan para mahasiswa untuk menyusun RPP. Berdasarkan hasil observasi awal yang diperoleh informasi bahwa dari 35 mahasiswa hanya 15 atau $43 \%$ yang mencapai nilai kriteria ketuntasan minimal (KKM) 70.

Pada pembelajaran dengan pemodelan dan pembelajaran berbasis projek ini, hasil belajar dilakukan dengan teknik tes tulis dan bentuk instrumen tes uraian. Hasil belajar penelitian ini adalah kemampuan menyusun RPP yang dilakukan dengan meneliti ketepatan komponen yang digunakan untuk menyusun RPP. Komponen RPP, meliputi (1) identitas mata pelajaran. Identitas sekolah, kelas/semester, dan topik; (2) alokasi waktu, (3) kompetensi inti, (4) kompetensi dasar dan indikator ketercapaian, (5) tujuan, (6) materi, (7) pendekatan, model, dan metode, (8) media dan sumber belajar, (9) langkah pembelajaran, (10) penilaian, dan (11) tanggal, tanda tangan pendidik, dan kepala sekolah.
Hasil belajar pada siklus 1 secara keseluruhan dapat dilihat pada tabel berikut.

Tabel 4 Rekapitulai Hasil Belajar Siklus 1

\begin{tabular}{cccc}
\hline No & Skor & Frekuensi & Persentase \\
\hline 1. & $86-100$ & 2 & $6 \%$ \\
\hline 2. & $70-85$ & 20 & $57 \%$ \\
\hline 3. & $60-69$ & 13 & $37 \%$ \\
\hline 4. & $41-59$ & 0 & 0 \\
\hline 5. & $0-40$ & 0 & 0 \\
\hline
\end{tabular}

Berdasarkan Tabel 4, yang mencapai KKM hanya 22 dari 35 mahasiswa. Hal itu berarti hasil belajar hanya $63 \%$.

Apabila setiap komponen RPP dicermati diperoleh informasi tentang bobot skor dan frekuensi sebagai berikut.

Tabel 5 Rekapitulai Hasil Belajar Siklus 1

\begin{tabular}{|c|c|c|c|c|}
\hline No & $\begin{array}{c}\text { Komponen } \\
\text { RPP }\end{array}$ & Frekuensi & Skor & $\%$ \\
\hline \multirow[t]{2}{*}{1.} & Identitas & $\mathrm{C}: 10$ & 95 & 68 \\
\hline & $\begin{array}{l}\text { Mata Pel- } \\
\text { ajaran dan } \\
\text { Sekolah }\end{array}$ & $\mathrm{B}: 25$ & & \\
\hline \multirow[t]{2}{*}{2.} & Alokasi & $\mathrm{C}: 15$ & 90 & 64 \\
\hline & Waktu & $\mathrm{B}: 20$ & & \\
\hline 3. & $\begin{array}{l}\text { Kompe- } \\
\text { tensi Inti }\end{array}$ & SB:35 & 140 & 100 \\
\hline \multirow[t]{2}{*}{4.} & Kompeten & $\mathrm{C}: 25$ & 80 & 57 \\
\hline & $\begin{array}{l}\text { si Dasar } \\
\text { dan Indi- } \\
\text { kator Ke- } \\
\text { tercapaian }\end{array}$ & B:10 & & \\
\hline \multirow[t]{2}{*}{5.} & Tujuan & $\mathrm{C}: 23$ & 82 & 59 \\
\hline & & $\mathrm{B}: 12$ & & \\
\hline \multirow[t]{2}{*}{6.} & Materi & $\mathrm{C}: 28$ & 78 & 56 \\
\hline & & $\mathrm{B}: 7$ & & \\
\hline \multirow[t]{2}{*}{7.} & Pendekat- & $\mathrm{C}: 27$ & 78 & 56 \\
\hline & $\begin{array}{l}\text { an, Model, } \\
\text { dan Meto- }\end{array}$ & $\mathrm{B}: 8$ & & \\
\hline \multirow[t]{2}{*}{ No } & $\begin{array}{c}\text { Komponen } \\
\text { RPP }\end{array}$ & Frekuensi & Skor & $\%$ \\
\hline & de & & & \\
\hline \multirow[t]{3}{*}{8.} & Media dan & $\mathrm{C}: 26$ & 79 & 57 \\
\hline & Sumber & B:9 & & \\
\hline & Belajar & & & \\
\hline \multirow[t]{2}{*}{9.} & Langkah & $\mathrm{C}: 25$ & 80 & 57 \\
\hline & $\begin{array}{l}\text { Pembel- } \\
\text { ajaran }\end{array}$ & B:10 & & \\
\hline 10. & Penilaian & $\mathrm{C}: 29$ & 76 & 54 \\
\hline
\end{tabular}


Volume 4, No. 1, Februari 2019

\begin{tabular}{llccc}
\hline & & B:6 & & \\
\hline 11. & Tanggal, & C:20 & 85 & 61 \\
& Tanda & B:15 & & \\
Tangan & & & \\
\hline Jumlah & & 963 & \\
\hline & Persentase \% & & & 63 \\
\hline
\end{tabular}

Untuk hasil penyusun RPP pada siklus 1 ini, satu komponen mendapat $100 \%$ karena hanya mencontoh dari kurikulum, yaitu komponen (3) kompetensi inti. Untuk kedelapan komponen lain pada siklus 2 harus diperbaiki.

Kesalahan pada komponen (1), yaitu identitas mata pelajaran, sekolah, kelas/semester, dan topik karena banyak mahasiswa yang menuliskan tidak lengkap. Kesalahan pada komponen (2) alokasi waktu terjadi karena mahasiswa masih banyak yang bingung cara menuliskan dengan tepat.

Kesalahan mahasiswa pada komponen (4) terjadi karena ketidaktepatan indikator. Hal itu terjadi karena ada beberapa perbedaan antara indikator yang ada pada kurikulum dengan buku guru dan buku siswa.

Kesalahan para mahasiswa pada komponen (5) terjadi karena tujuan yang dibuat belum secara lengkap memuat unsur audien, behaviour, condition, dan degree $(A B C D)$. Selain itu, banyak mahasiswa yang tidak tepat membuat condition serta lupa memberi degree.

Kesalahan pada komponen (6), yaitu materi tidak relevan dengan indikator yang telah ditetapkan. Selain itu, para mahasiswa tidak memuat secara rinci materi yang ditetapkan.

Kesalahan pada komponen (7), yaitu ketidaktepatan model yang digunakan karena tidak sesuai dengan materi.
Padahal, model pembelajaran harus dipilih secara tepat untuk mendukung pemahaman siswa. Hal tersebut juga terjadi pada komponen (8) karena pemilihan media yang tidak tepat sebagai sarana menyampaikan pesan pada materi.

Kesalahan komponen (9), yaitu penetapan langkah pembelajaran tidak selaras dengan model yang telah ditetapkan. Banyak mahasiswa yang menggunakan langkah secara sembarangan; tidak menaati urutan atau sintaks model yang dipilih.

Kesalahan komponen (10), yaitu banyak mahasiswa yang tidak tepat menetapkan teknik penilaian. Bila tekniknya sudah benar, ternyata masih ada kesalah bentuk instrumennya. Selain itu, banyak mahasiswa yang menyediakan penilaian secara berlebihan, misalnya untuk menilai sikap dilakukan dengan jurnal, observasi, penilaian diri, dan penilaian sejawat. Seharusnya, dipilih sesuai dengan kebutuhan materi. Hal tersebut juga terjadi pada penilaian pengetahuan dan keterampilan.

Kesalahan komponen (11) terjadi pada penanggalan. Banyak mahasiswa yang tidak logis memberikan tanggal. Banyak penanggalan yang diterakan justru setelah pelaksanaan sehingga tidak logis.

Hasil belajar pada siklus 1, ditinjau secara klasikal melalui ketercapaian KKM dan persentase untuk setiap komponen RPP menjadi perhatian pada langkah refleksi. Dengan begitu, pada siklus 2, hasil refleksi tersebut dapat digunakan untuk menetapkan langkah yang tepat. 
Jurnal Belajar Bahasa, ISSN 2502-5864, E-ISSN 2503-0329

Volume 4, No. 1, Februari 2019

Pada siklus 2, hasil belajar yang diperoleh secara keseluruhan dapat dilihat pada tabel berikut.

Tabel 6 Rekapitulai Hasil Belajar Siklus 2

\begin{tabular}{cccc}
\hline No & Skor & Frekuensi & Persentase \\
\hline 1. & $86-100$ & 6 & $17 \%$ \\
\hline 2. & $70-85$ & 23 & $66 \%$ \\
\hline 3. & $60-69$ & 6 & $17 \%$ \\
\hline 4. & $41-59$ & 0 & 0 \\
\hline 5. & $0-40$ & 0 & 0 \\
\hline
\end{tabular}

Berdasarkan Tabel 6, yang mencapai KKM ada 29 mahasiswa. Hal itu berarti hasil belajar pada siklus 2 menjadi $83 \%$.

Hasil pada siklus 1 ke siklus 2 menunjukkan peningkatan yang signifikan. Dari hasil awal hingga siklus 1 diperoleh kenaikan 20\%. Dari hasil siklus 1 hingga siklus 2 diperoleh kenaikan 20\%.

Apabila setiap komponen RPP dicermati, ternyata juga terjadi peningkatan pada skor perolehan maupun persentasenya. Berikut ini tabel rekapitulasi komponen RPP beserta frekuensi, skor, dan persentase pada siklus 2.

Tabel 7 Rekapitulai Hasil Belajar Siklus 2

\begin{tabular}{|c|c|c|c|c|}
\hline No & $\begin{array}{c}\text { Komponen } \\
\text { RPP }\end{array}$ & Frekuensi & Skor & $\%$ \\
\hline 1. & $\begin{array}{l}\text { Identitas } \\
\text { Mata Pel- } \\
\text { ajaran dan } \\
\text { Sekolah }\end{array}$ & SB:35 & 140 & 100 \\
\hline 2. & $\begin{array}{l}\text { Alokasi } \\
\text { Waktu }\end{array}$ & SB:35 & 140 & 100 \\
\hline 3. & $\begin{array}{l}\text { Kompe- } \\
\text { tensi Inti }\end{array}$ & SB:35 & 140 & 100 \\
\hline No & $\begin{array}{c}\text { Komponen } \\
\text { RPP }\end{array}$ & Frekuensi & Skor & $\%$ \\
\hline 4. & $\begin{array}{l}\text { Kompeten } \\
\text { si Dasar } \\
\text { dan Indi- } \\
\text { kator Ke- } \\
\text { tercapaian }\end{array}$ & $\begin{array}{c}\mathrm{C}: 3 \\
\mathrm{~B}: 25 \\
\mathrm{SB}: 7\end{array}$ & 105 & 75 \\
\hline 5. & Tujuan & $\begin{array}{c}\mathrm{C}: 3 \\
\mathrm{~B}: 30 \\
\mathrm{SB}: 2\end{array}$ & 104 & 74 \\
\hline
\end{tabular}

\begin{tabular}{|c|c|c|c|c|}
\hline 6. & Materi & $\begin{array}{c}C: 8 \\
B: 22 \\
S B: 5\end{array}$ & 102 & 73 \\
\hline 7. & $\begin{array}{l}\text { Pendekat- } \\
\text { an, Model, } \\
\text { dan Meto- } \\
\text { de }\end{array}$ & $\begin{array}{c}C: 7 \\
B: 20 \\
S B: 8\end{array}$ & 106 & 76 \\
\hline 8. & $\begin{array}{l}\text { Media dan } \\
\text { Sumber } \\
\text { Belajar }\end{array}$ & $\begin{array}{c}C: 3 \\
B: 27 \\
S B: 5\end{array}$ & 107 & 76 \\
\hline 9. & $\begin{array}{l}\text { Langkah } \\
\text { Pembel- } \\
\text { ajaran }\end{array}$ & $\begin{array}{c}C: 3 \\
B: 27 \\
S B: 5\end{array}$ & 107 & 76 \\
\hline 10. & Penilaian & $\begin{array}{l}C: 5 \\
B: 25 \\
\text { SB:5 }\end{array}$ & 105 & 75 \\
\hline 11. & $\begin{array}{l}\text { Tanggal, } \\
\text { Tanda } \\
\text { Tangan }\end{array}$ & $\begin{array}{c}C: 5 \\
B: 25 \\
\text { SB:5 }\end{array}$ & 105 & 75 \\
\hline & Jumlah & & 1272 & \\
\hline & Persentase (\%) & & & 83 \\
\hline
\end{tabular}

Skor dan persentase kedelapan komponen RPP meningkat dari siklus 1 ke siklus 2. Pada komponen (1) identitas mata pelajaran, sekolah, kelas/semester, dan topik meningkat $32 \%$, (2) alokasi waktu meningkat 3\%, dan (3) kompetensi dasar dan indikator ketercapaian meningkat $18 \%$, (4) tujuan meningkat $15 \%$, (5) materi meningkat $17 \%$, pendekatan, model, dan metode meningkat 20\%, (7) media dan sumber belajar meningkat 19\%, (8) langkah pembelajaran meningkat $19 \%$, penilaian meningkat $21 \%$, dan tanggal, tanda tangan pendidik dan kepala sekolah meningkat $14 \%$.

Kriteria hasil belajar mahasiswa berupa kemampuan menyusun RPP dari observasi awal, siklus 1, dan siklus 2 terlihat pada tabel berikut.

Tabel 8 Kriteria Hasil Belajar

\begin{tabular}{|c|c|c|c|c|}
\hline \multirow{2}{*}{$\begin{array}{c}\text { Interval } \\
\%\end{array}$} & \multirow{2}{*}{ Kriteria } & \multicolumn{3}{|c|}{ Persentase (\%) } \\
\hline & & Obs & Sk 1 & Sk 2 \\
\hline $86-100$ & Sangat Baik & & & \\
\hline
\end{tabular}


Volume 4, No. 1, Februari 2019

\begin{tabular}{cccc}
\hline $70-85$ & Baik & & 83 \\
\hline $60-69$ & Cukup & 63 & \\
\hline $41-59$ & Kurang & 43 & \\
\hline $0-40$ & Sangat Kurang & & \\
\hline
\end{tabular}

Berdasarkan tabel tersebut, hasil belajar para mahasiswa setelah penerapan pemodelan dan pembelajaran berbasis projek mengalami peningkatan. Dari $43 \%$ dengan kriteria 'kurang' pada observasi awal menjadi 63\% dengan kriteria 'cukup' pada siklus 1 dan lebih meningkat menjadi 83\% dengan kriteria 'baik' pada siklus 2 . Masing-masing meningkat $20 \%$.

Peningkatan hasil belajar setelah penerapan pemodelan dan pembelajaran berbasis projek dilihat secara jelas pada grafik berikut ini.

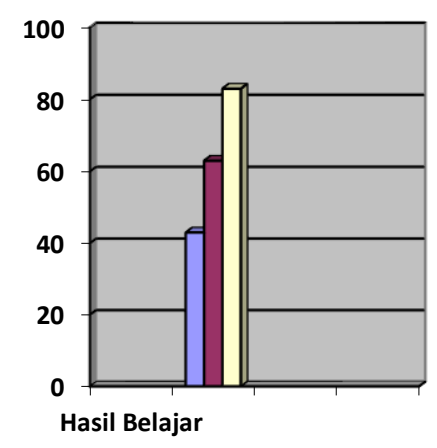

口Observasi Awal

口Siklus 1

口Siklus 2

Grafik 2 Peningkatan Hasil Belajar

\section{c. Respon Mahasiswa}

Respon mahasiswa terhadap penerapan pemodelan dan pembelajaran berbasis projek diperoleh melalui angket dilaksanakan. Pengisian angket dilakukan sebanyak tiga kali, yaitu pada observasi awal, siklus 1 dan siklus 2. Akan tetapi, pertanyaan yang digunakan pada angket observasi awal ada yang berbeda dengan siklus 1 dan siklus 2. Angket pada observasi awal berhubungan dengan pembelajaran yang dilakukan sebelum penerapan pemodelan dan pembelajaran berbasis projek. Angket pada siklus 1 dan siklus 2 berhubungan dengan penerapan pemodelan dan pembelajaran berbasis projek.

Respon mahasiswa terhadap pembelajaran pada observasi awal tampak pada tabel berikut.

Tabel 9 Hasil Respon Mahasiswa pada Observasi Awal

\begin{tabular}{|c|c|c|c|}
\hline No & Pertanyaan & Frekuensi & Skor \\
\hline \multirow[t]{3}{*}{1} & Pembelajaran yang & $\mathrm{K}: 15$ & 55 \\
\hline & dilaksanakan dosen & $C: 15$ & \\
\hline & $\begin{array}{l}\text { selama ini menye- } \\
\text { nangkan }\end{array}$ & B:5 & \\
\hline \multirow[t]{3}{*}{2} & Pembelajaran yang telah & $\mathrm{K}: 15$ & 41 \\
\hline & dilakukan selama ini & $C: 15$ & \\
\hline & bervariasi dan inovatif? & $\mathrm{B}: 5$ & \\
\hline \multirow[t]{2}{*}{3} & Pembelajaran yang telah & $C: 25$ & 80 \\
\hline & $\begin{array}{l}\text { dilakukan selama ini } \\
\text { membuat pemahaman } \\
\text { pada materi lebih baik }\end{array}$ & $\mathrm{B}: 10$ & \\
\hline \multirow[t]{2}{*}{4} & Pembelajaran yang di- & C:30 & 75 \\
\hline & $\begin{array}{l}\text { lakukan selama ini mem- } \\
\text { bantu untuk mendapat } \\
\text { contoh konkrit }\end{array}$ & B:5 & \\
\hline \multirow[t]{2}{*}{5} & Pembelajaran yang dila- & $\mathrm{K}: 15$ & 55 \\
\hline & $\begin{array}{l}\text { kukan membuat Anda } \\
\text { berpikir kritis }\end{array}$ & C:20 & \\
\hline \multirow[t]{2}{*}{6} & Pembelajaran yang telah & $\mathrm{K}: 25$ & 45 \\
\hline & $\begin{array}{l}\text { dilakukan membuat ker- } \\
\text { jasama dengan teman } \\
\text { sejawat menjadi lebih } \\
\text { baik }\end{array}$ & C:10 & \\
\hline \multirow[t]{2}{*}{7} & Pembelajaran yang telah & $\mathrm{K}: 25$ & 45 \\
\hline & $\begin{array}{l}\text { dilakukan membuat } \\
\text { kemampuan berkomu- } \\
\text { nikasi Anda menjadi } \\
\text { lebih baik }\end{array}$ & C:10 & \\
\hline No & Pertanyaan & Frekuensi & Skor \\
\hline \multirow[t]{4}{*}{8} & Pembelajaran yang telah & $C: 25$ & 50 \\
\hline & $\begin{array}{l}\text { dilakukan membuat pe- } \\
\text { ningkatan hasil belajar }\end{array}$ & $B: 10$ & \\
\hline & Jumlah & & 500 \\
\hline & Persentase (\%) & & 45 \\
\hline
\end{tabular}

Berdasarkan Tabel 9 tersebut diketahui bahwa respon mahasiswa pada observasi awal hanya 45\%. Dari delapan aktivitas, 
Jurnal Belajar Bahasa, ISSN 2502-5864, E-ISSN 2503-0329

Volume 4, No. 1, Februari 2019

lima di antaranya memunyai respon dengan kriteria 'kurang'; sebanyak 95 atau 9\%. Respon yang memunyai kriteria 'cukup' sebanyak 300 atau 27\%. Respon yang memunyai kriteria 'baik' sebanyak 105 atau $9 \%$.

Respon mahasiswa setelah penerapan pemodelan dan pembelajaran berbasis projek pada siklus 1 maupun siklus 2 terlihat pada tabel berikut ini.

Tabel 10 Hasil Angket Siklus 1 dan 2

\begin{tabular}{|c|c|c|c|c|}
\hline \multirow{2}{*}{ No } & \multirow{2}{*}{$\begin{array}{l}\text { Aspek yang } \\
\text { Ditanyakan }\end{array}$} & \multicolumn{2}{|c|}{ Frekuensi } & Skor \\
\hline & & 1 & 2 & 1 \\
\hline \multirow[t]{3}{*}{1} & Pembelajar- & $\mathrm{C}: 19$ & $C: 6$ & \multirow[t]{3}{*}{86121} \\
\hline & an yang dila- & $\mathrm{B}: 16$ & $\mathrm{~B}: 15$ & \\
\hline & $\begin{array}{l}\text { kukan me- } \\
\text { nyenangkan }\end{array}$ & & SB:14 & \\
\hline \multirow[t]{3}{*}{2} & Pembelajar- & $C: 20$ & $C: 5$ & \multirow[t]{3}{*}{85112} \\
\hline & an yang dila- & $\mathrm{B}: 15$ & B:18 & \\
\hline & $\begin{array}{l}\text { kukan ino- } \\
\text { vatif }\end{array}$ & & SB:12 & \\
\hline \multirow[t]{6}{*}{3} & Pembelajar- & $C: 16$ & C:6 & \multirow[t]{6}{*}{89108} \\
\hline & an yang dila- & $\mathrm{B}: 19$ & $B: 20$ & \\
\hline & kukan mem- & & SB:9 & \\
\hline & $\begin{array}{l}\text { buat pema- } \\
\text { haman pada }\end{array}$ & & & \\
\hline & materi lebih & & & \\
\hline & baik & & & \\
\hline \multirow[t]{6}{*}{4} & Pembelajar- & C:14 & C:4 & \multirow[t]{6}{*}{91112} \\
\hline & an yang di- & $\mathrm{B}: 21$ & $\mathrm{~B}: 20$ & \\
\hline & lakukan & & SB:11 & \\
\hline & membantu & & & \\
\hline & untuk men- & & & \\
\hline & $\begin{array}{l}\text { dapat con- } \\
\text { toh konkrit }\end{array}$ & & & \\
\hline \multirow[t]{3}{*}{5} & Pembelajar- & $C: 16$ & $C: 6$ & \multirow[t]{3}{*}{89108} \\
\hline & an yang dila- & $\mathrm{B}: 19$ & $B: 20$ & \\
\hline & $\begin{array}{l}\text { kukan me- } \\
\text { ningkatkan }\end{array}$ & & SB:9 & \\
\hline \multirow[t]{5}{*}{ No } & Aspek yang & \multicolumn{2}{|c|}{ Frekuensi } & Skor \\
\hline & Ditanyakan & 1 & 2 & 1 \\
\hline & kemampuan & & & \\
\hline & berpikir & & & \\
\hline & kritis & & & \\
\hline \multirow[t]{5}{*}{6} & Pembelajar- & $\mathrm{C}: 13$ & $C: 3$ & \multirow[t]{5}{*}{92112} \\
\hline & an yang dila- & $B: 22$ & $\mathrm{~B}: 22$ & \\
\hline & kukan me- & & SB:10 & \\
\hline & ningkatkan & & & \\
\hline & kemampuan & & & \\
\hline
\end{tabular}

\begin{tabular}{|c|c|c|c|c|}
\hline & $\begin{array}{l}\text { mengomuni } \\
\text { kasikan ide }\end{array}$ & & & \\
\hline 7 & $\begin{array}{l}\text { Pembelajar- } \\
\text { an yang dila- } \\
\text { kukan mem- } \\
\text { buat kerjasa- } \\
\text { ma dengan } \\
\text { teman seja- } \\
\text { wat menjadi } \\
\text { lebih baik }\end{array}$ & $\begin{array}{l}\mathrm{C}: 13 \\
\mathrm{~B}: 22\end{array}$ & $\begin{array}{c}\text { C:6 } \\
\text { B:20 } \\
\text { SB:9 }\end{array}$ & 92108 \\
\hline 8 & $\begin{array}{l}\text { Pembelajar- } \\
\text { an yang di- } \\
\text { lakukan me- } \\
\text { ningkatkan } \\
\text { kreativitas } \\
\text { Anda }\end{array}$ & $\begin{array}{l}\mathrm{C}: 30 \\
\mathrm{~B}: 5\end{array}$ & $\begin{array}{c}\text { C:6 } \\
\text { B:19 } \\
\text { SB:10 }\end{array}$ & 75109 \\
\hline 9 & $\begin{array}{l}\text { Pembelajar- } \\
\text { an yang dila- } \\
\text { kukan me- } \\
\text { ningkatkan } \\
\text { kemampuan } \\
\text { untuk meng- } \\
\text { hasilkan } \\
\text { produk yang } \\
\text { baik dan } \\
\text { benar }\end{array}$ & $\begin{array}{l}\mathrm{C}: 14 \\
\mathrm{~B}: 21\end{array}$ & $\begin{array}{c}C: 7 \\
B: 12 \\
S B: 16\end{array}$ & 91126 \\
\hline \multirow[t]{3}{*}{10} & $\begin{array}{l}\text { Pembelajar- } \\
\text { an yang te- } \\
\text { lah dilaku- } \\
\text { kan mem- } \\
\text { buat pening- } \\
\text { katan hasil } \\
\text { belajar }\end{array}$ & $\begin{array}{l}\mathrm{C}: 12 \\
\mathrm{~B}: 23\end{array}$ & $\begin{array}{c}\text { C:5 } \\
\text { B:23 } \\
\text { SB:7 }\end{array}$ & 93107 \\
\hline & Jumlah & & & $883 \quad 1123$ \\
\hline & Persentase (\%) & & & 63 \\
\hline
\end{tabular}

Untuk respon mahasiswa pada siklus 1 sudah tidak ada kriteria 'kurang', tetapi kriteria 'cukup' dan 'baik'. Dari 10 aktivitas diperoleh respon dengan jumlah sebanyak 883 atau 63\%. Respon dengan kriteria 'cukup' sebanyak 334 atau 24\%. Respon dengan kriteria 'baik' sebanyak 549 atau $39 \%$.

Setelah pelaksanaan siklus 2, respon mahasiswa meningkat lagi. Hal tersebut disebabkan seluruh aktivitas juga sudah ada yang mendapat kriteria 'sangat baik'. Secara keseluruhan, respon mahasiswa pada siklus 2 sebanyak 1123 atau 80\%. 
Respon dengan kriteria 'cukup' sebanyak 108 atau 8\%. Respon yang memunyai kriteria 'baik' sebanyak 579 atau 41\%. Respon yang memunyai kriteria 'sangat baik' sebanyak 436 atau 31\%.

Berdasarkan data-data hasil angket, respon mahasiswa mengalami peningkatan. Pada observasi awal diperoleh respon sebanyak $45 \%$ kemudian meningkat menjadi $63 \%$ pada siklus 1 dan meningkat menjadi $80 \%$ pada siklus 2 . Untuk lebih jelas dapat dilihat pada tabel kriteria respon mahasiswa berikut ini.

Tabel 11 Kriteria Respon Mahasiswa

\begin{tabular}{|c|c|c|c|c|}
\hline \multirow{2}{*}{$\begin{array}{c}\text { Interval } \\
\%\end{array}$} & \multirow{2}{*}{ Kriteria } & \multicolumn{3}{|c|}{ Persentase (\%) } \\
\hline & & Obs & Sk 1 & Sk 2 \\
\hline $86-100$ & Sangat Baik & & & \\
\hline $70-85$ & Baik & & & 80 \\
\hline $60-69$ & Cukup & & 63 & \\
\hline $41-59$ & Kurang & 45 & & \\
\hline $0-40$ & Sangat Kurang & & & \\
\hline
\end{tabular}

Peningkatan respon mahasiswa secara keseluruah terlihat jelas melalui grafik berikut.

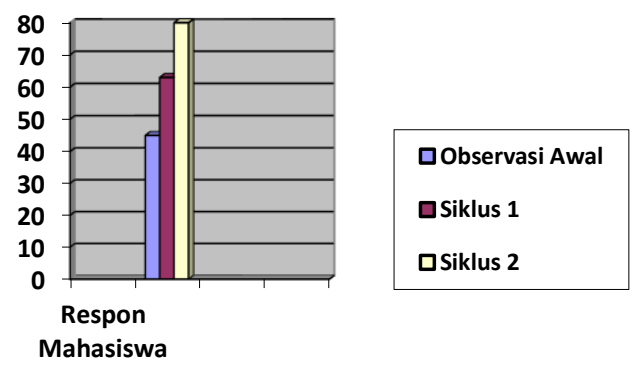

Grafik 3 Respon Mahasiswa

Respon mahasiswa dari observasi awal ke siklus 1 meningkat 18\%. Respon dari siklus 1 ke siklus 2 meningkat $17 \%$

\section{SIMPULAN}

Berdasarkan hasil penelitian dapat disimpulkan tiga hal. a. Terjadi peningkatan penerapan pemodelan dan pembelajaran berbasis projek pada mata kuliah Perencanaan PBSI untuk meningkatkan kemampuan mahasiswa menyusun RPP; tampak pada aktivitas dosen dan aktitas mahasiswa dari kriteria 'baik' pada menjadi 'sangat baik'.

b. Terjadi peningkatan hasil belajar mahasiswa untuk menyusun RPP setelah menggunakan pemodelan dan pembelajaran berbasis projek dari kriteria 'cukup' menjadi 'baik'.

c. Terjadi peningkatan respon mahasiswa setelah menggunakan pemodelan dan pembelajaran berbasis projek untuk meningkatkan kemampuan mahasiswa menyusun RPP dari kriteria 'cukup' menjadi 'baik'.

\section{DAFTAR RUJUKAN}

Baker, E., Breanna T., Patricia O., Margaret., Lynne F. (2011). Projectbased Learning Model, Relevant Learning for the 21st Century. Washington: Pacific Education Institute. Grant, M.M. (2002). Getting A Grip of Pembelajaran Berbasis Projek: Theory, Cases and Recomandation. North Carolina: Meredian a Middle School Computer Technologies. Journal vol 5.

Klein, J.I., Santiago T., Sabrina H. K., Anna C., Linda C., Barbara R. (2009). ProjectBased Learning: Inspiring Middle School Student to Engage in Deep and Active Learning. New York: NYC Departement of Education.

Departemen Pendidikan Nasional. (2005). Undang-undang Republik Indonesia Nomor 14 Tahun 2005 Pasal 10 (Ayat 1). Jakarta: Depdiknas 
Kementerian Pendidikan dan Kebudayaan. (2016). Peraturan Menteri Pendidikan Dan Kebudayaan Republik Indonesia Nomor 22 Tahun 2016 tentang Standar Proses Pendidikan Dasar Dan Menengah. Jakarta: Kemdikbud.

Mulyasa, E. (2008). Menjadi Guru Profesional(Menciptakan Pembelajaran Kreatif dan Menyenangkan). Bandung: PT Remaja Rosdakarya.

Nurhadi. (2005). Pendekatan Kontekstual. Malang: Universitas Negeri Malang.

Priyatni, Endah Tri. 2002. "Penerapan Konsep dan Prinsip Pengajaran dan Pembelajaran dan Pembelajaran Kontekstual dalam Pembelajaran Bahasa Indonesia". Dalam Kumpulan Materi TOT CTL Mata Pelajaran Bahasa Indonesia Sekolah Lanjutan Tingkat Pertama. Jakarta: Depdiknas

$\begin{array}{cr}\text { Safardi. (2009). } & \text { "Meningkatkan } \\ \text { Kemampuan } & \text { Guru }\end{array}$
Kewarganegaraan dalam Menyusun Rencana Pelaksanaan Pembelajaran (RPP) melalui Focus Discussion pada SMAS Muhammadiyah Pekanbaru". Tesis. Tidak Dipublikasikan. Program Pascasarjana Magister Pendidikan Universitas Pendidikan Indonesia.

The George Lucas Educational Foundation. 2005. Instructional Module Project Based Learning. (Http//www.edutopia. org.modules/PBL/whatpbl.php).

Diunduh 25 November 2018. Pukul 12.00 WIB.

Wijaya. (2011). "Peningkatan Kemampuan Guru dalam Menyusun Rencana Pelaksanaan Pembelajaran (RPP) melalui Supervisi Klinis dan Implikasinya terhadap Pembelajaran IPS di SMP Negeri 2 Wlingi Kabupaten Blitar. Tesis. Tidak Dipublikasikan. Universitas Muhammadiyah Malang. 